\author{
Arsen Bačić, redoviti profesor u trajnom zvanju ${ }^{1}$ \\ Petar Bačić, izvanredni profesor ${ }^{2}$
}

\title{
DEKONSTRUKCIJA ADMINISTRATIVNE DRŽAVE I MOGUĆNOSTI JAVNOG PRAVA
}

UDK: 342

Primljeno:20. kolovoza 2018.

Izvorni znanstveni rad

\begin{abstract}
U tekstu se rastvara pojam „dekonstrukcije“ administrativne države u SAD-u kao njen reprezentativni primjer. Polazeći od dominacije moderne administrativne države, puna slika suvremenog konstitucionalizma u SAD-u mora uključivati administrativni konstitucionalizam kao svekoliko razumijevanje i interpretaciju suvremene administrativne države i njene strukture od strane agencija i drugih aktivnih aktera upravnoga prava. Administrativni konstitucionalizam danas je jedan od najintenzivnije izučavanih predmeta istraživanja komparativnog ustavnog i upravnog prava. Razlog egzegeze ovoga pitanja nisu samo njegove različite dimenzije već i činjenica da on predstavlja glavni mehanizam kojim se danas elaborira i implementira ustavno značenje.
\end{abstract}

Ključne riječi: administrativna država, dekonstrukcija administrativne države, administrativni konstitucionalizam, ustavno pravo, upravno pravo

I am increasingly admiring of Donald Trump. I have become more and more convinced that there is a method in his madness.

Boris Johnson (2018)

$* * *$

1. Uvodna napomena; 2. Ukratko o pojmu dekonstrukcije i njegovu značenju u pravu; 2.1. Dekonstrukcija i njena primjena u pravu; 3. Administrativna država: postanak i utjecaj na sistem ograničene vlade; 3.1. Founding fathers i progresisti - razlike u percepciji dobre vladavine; 3.2 . Administrativna država i ustavni dokumenti 20. i 21. stoljeća; 4. Administrativni konstitucionalizam

${ }^{1}$ Arsen Bačić, akademik, redoviti član Hrvatske akademije znanosti i umjetnosti, redoviti profesor Ustavnog prava u trajnom zvanju na Pravnom fakultetu u Splitu, bacic@pravst.hr, Pravni fakultet Sveučilišta u Splitu, Domovinskog rata 8, 21000 Split, Hrvatska

2 Dr. sc. Petar Bačić, izvanredni profesor Pravnog fakulteta u Splitu, pbacic@pravst.hr, Pravni fakultet Sveučilišta u Splitu, Domovinskog rata 8, 21000 Split, Hrvatska. Tekst je pripremljen za znanstveni skup Francusko-hrvatski upravni dani, rujan 2018. Dijelove rada: t. 1., 2., 2.1. i 6. napisao A. B.; t. 3., 3.1., 3.2., 4., 5. i 5.1. napisao P. B.

3 B. Johnson, cit. pr. William Davies, ,Johnson, Trump and the rise of radical incompetence“, The New York Times - International Edition, Saturday-Sunday, July 14-15, 2018., p. 9. 
i pitanje odgovornosti i legitimiteta u administrativnoj državi; 5. Dekonstrukcija administrativne države i promjene upravnog prava: međuzavisnost i podešavanje; 5.1. Bannonova dekonstrukcija države taking seriously? 6. Zaključak.

$* * *$

\section{UVODNA NAPOMENA}

U jednom od brojnih recentnih komentara koji danas prate i analiziraju „rast radikalne nekompetencije“ i posljedice toga po suvremenu državu, kritički pisci još broje političare novoga kova ${ }^{4}$ u kolonama na čijem čelu danas stoje brojni les notables (uglednici) poput Donalda Trumpa, Borisa Johnsona i silni drugi. Prema Williamu Daviesu, piscu knjige Nervous State: How Feeling Took Over the World, ${ }^{5}$ ono što spaja takve radikale kao reakcionarne populiste s jedne strane i nacionaliste širom svijeta s druge strane jest njihovo omalovažavanje same ideje vladanja kao kompleksnog, modernog, na činjenicama zasnovanog niza aktivnosti za koje se traže tehnička ekspertiza i stalni službenici. U bespoštednoj kritici nove vladajuće klase, studija W. Daviesa pokušava razumjeti pojavu reakcionarnog populizma kao osvetu državnog suvereniteta. Nije riječ o naglom vraćanju na nešto što je nekad postojalo prije dekada globalizacije, već prije o zazoru protiv oblika političke vlasti koja ju je omogućavala, koja je tehnokratska, multilateralna i neopisivo odvojena od lokalnih identiteta. U Europi nam za to poučan primjer pruža Europska komisija koja je, mada obilatog vladavinskog kapaciteta, ali zato permanentno žedna suvereniteta, postala istureni cilj za suvereniste - nacionaliste poput mađarskog premijera Viktora Urbana. ${ }^{6}$

U ovoj ofenzivi radikalnih populista već se prepričava i analizira događaj neposredno nakon ulaska D. Trumpa u White House kada je predsjednikov glavni strateg Stephen K. Bannon izrazio želju da novoformirani kabinet ostvari „dekonstrukciju administrativne države“! Dekonstrukcija administrativne države postavljena je kao bojna zastava, ratni poklič republikanske egzekutive, štoviše kao jedan od najvažnijih ciljeva Trumpove administracije. No, na što je zapravo mislio S. Bannon pod ,dekonstrukcijom administrativne države“"? Što je konkretno imala značiti ta najava bučne ofenzive rušenja postojeće administrativne države

4 New Statesman, nagrađivana engleska TV-serija s Rikom Mayallom u glavnoj ulozi, remek-djelo političke satire o ex-konzervativnom parlamentarcu Alanu B'Stardu koji počinje svoj novi politički život kao europski predstavnik za unutarnje poslove. The B'stard File: The New Statesman Exposé, by Rik Mayall, https://www.goodreads.com/book/show/1979799.The_B_stard_File; https://www.theguardian. com/tv-and-radio/2017/may /06/alan-bstard-rik-mayall-new-statesman-post-truth-satire.

5 William Davies, „Johnson, Trump and the rise of radical incompetence“, The New York Times International Edition, Saturday-Sunday, July 14-15, 2018., p. 9.

6 D. Brooks, ,Reshaping a localist revolution“, The New York Times - International edition, SaturdaySunday, July 21-22, 2018., p. 1, p. 13. 
kao metafore narasle moći birokrata i njihova političko-pravnog arsenala s kojim oni već dugo potkopavaju samu ideju predstavničke vlade? Vraća li se čemu nova administracija pod vodstvom kontroverznog američkog predsjednika i njemu sličnih? Na koji način identificirati ono što je doktrinarno važno za vladavinsko pravo u lakonskim twitterima šefa američke egzekutive kao vrhuncu njegove komunikativne kompetencije? ${ }^{7}$ Koje bi bile osnove takvog deskriptivnog projekta koji poziva na „probijanje površine odluka i akademskih komentara“ u cilju otkrivanja (ne)iskazanih pretpostavki politike, ali i epistemološke zaloge na kojima počiva recentna struja nositelja dekonstrukcije administrativne države? Koja je alternativa i što ostaje nakon nje?

U ovom tekstu pokušat ćemo osvijetliti ideju i pojavu dekonstrukcije države, posebno dekonstrukcije administrativne države i pronaći razloge neprijateljstva suvremenih populista prema tipu države koja je fenomen administracije i socijalnog blagostanja posredstvom administrativnog konstitucionalizma dovela do vrhunca. U tom smislu pokušat ćemo pronaći i vezu između dekonstrukcije administrativne države i onog značajnog dijela upravnog (administrativnog) prava koji se nalazi u rukama ,brojnih političkih, institucionalnih i ekonomskih aktera angažiranih u borbi, interakciji i pregovorima, od kojih svatko kao racionalni agent i manipulirajući upravnim pravom nastoji maksimalizirati svoj boljitak“."

\section{UKRATKO O POJMU DEKONSTRUKCIJE I NJEGOVU ZNAČENJU U PRAVU}

Pojam dekonstrukcije filozofski je konstrukt Martina Heideggera (1889. - 1976.) i Jacquesa Derride (1930. - 2004.), koji je iz metafizike ovih dvaju istaknutih filozofa 20. stoljeća postao sastavni dio intelektualnog aparata u nizu drugih područja društvenih znanosti (prava, politike, književnosti...). Riječ je o specifičnim tehnikama i filozofskim idejama koje su posebno J. Derrida i njegovi sljedbenici primjenjivali na različite tekstove. J. Derrida je dekonstrukciju definirao kao...

... promišljanje strukturirane genealogije filozofskih koncepata na najiskreniji unutrašnji način, ali u isto vrijeme i determinaciju iz neke određene izvanjskosti filozofije kojoj nije moguće kvalificirati ili imenovati ono što je povijest bila u stanju prikriti ili zabraniti, i uključivati se u povijest sredstvima tako... motivirane represije. ${ }^{10}$

\footnotetext{
7 M. S. Schmidt, „Trump's Twitter posts are said to be part of obstruction inquiry“, The New York Times - International edition, Saturday-Sunday, July 28-29, 2018, p. 1, p. 13.

8 M. Tushnet, „Critical Legal Studies and Constitutional Law: An Essay in Deconstruction“, 36 Stan. L. Rev. 623 (1984.), p. 627

9 G. Napolitano, Conflicts and strategies in administrative law I•CON (2014.), Vol. 12 No. 2, 357 369, doi:10.1093/icon/ mou017.

10 Nancy J. Holland, Deconstruction, https://www.iep.utm.edu/deconst/
} 
U pravnim tekstovima pojam dekonstrukcije koristi se ponajviše radi odgovora na pitanje zašto su legalne doktrine kontradiktorne, ideološki pristrane i neodređene. Tim se tehnikama otkrivaju skrivene antinomije u jeziku i mislima, a u praksi pravnim teoretičarima pomažu otvarati važna filozofska pitanja. ${ }^{11} \mathrm{~J}$. M. Balkin ističe da bi pravnici trebali biti zainteresirani za tehnike dekonstrukcije iz najmanje tri razloga. Prvo, dekonstrukcija osigurava metodu kritike postojećih pravnih doktrina; dekonstruktivno nam čitanje pokazuje kako argumenti koji nam se nude kao podrška jednom posebnom pravilu zapravo potkopavaju sami sebe i, umjesto toga, bivaju podrška sasvim opozitnom pravilu. Drugo, dekonstruktivne kritike mogu nam pokazati kako doktrinarni argumenti ispunjavaju i prikrivaju ideološko razmišljanje, što može biti od koristi ne samo pravniku koji traži reformu postojećih institucija, već i pravnom filozofu i pravnom historičaru. Treće, dekonstruktivne tehnike nude ne samo novu vrst interpretativne strategije nego i kritiku konvencionalnih interpretacija pravnih tekstova. Imajući to u vidu, možemo zaključiti da adaptacija Derridinih ideja na probleme legalne i političke misli najprije otkriva interes prema povezanosti (i nepovezanosti) između onoga što želimo reći i znakova koje koristimo da bismo objasnili određena naša značenja. Ukratko, Derrida je zainteresiran za tumačenje tekstova, a to pravnicima nije strano područje jer oni ionako najveći dio svog vremena koriste pokušavajući razumjeti što su im njihovi suborci ili protivnici pokušali kazati u svojim pravnim tekstovima. ${ }^{12}$

\subsection{Dekonstrukcija i njena primjena u pravu}

Legalne doktrine reflektiraju i reguliraju društveni život. Izbor zaštićenih prava i tehnika za njihovo ostvarivanje, ma koliko one bile jasne ili nejasne, reflektira nam poglede na društvene odnose. Mogu se navesti primjeri zakona koji dozvoljavaju (omogućuju) diskriminaciju po osnovi rase ili spola. Takvo zakonodavstvo priča drugačiju priču o ljudima nego li zakoni koji zabranjuju takvu diskriminaciju. Principi socijalne teorije poput liberalizma pričaju priču o ljudskoj prirodi koju neki prihvaćaju, a neki kritiziraju. I najmanje značajne ili neutralne doktrine i pravila u cjelini imaju neku priču kad bismo bili voljni čuti je.

Kad govorimo o pravnom sistemu, mislimo na pokušaj zajednice da realizira ljudske ciljeve što pretpostavlja deskripciju onoga što je dobro i što je loše u našoj prirodi: zapravo, radi se o tome što hoćemo od svojih života i koja bi mu bila ograničenja. Takva deskripcija nužno uključuje privilegiranje određenih aspekata

11 O tome na koji se način pojam dekonstrukcije koristi u pravu v. J. M. Balkin, „Decontructive practice and legal theory“, 96 Yale L. J. 743 (1987.); Dalton, „An Essay in the Deconstruction of Contract Doctrine“, 94 Yale L. J. 997 (1985.); Frug, ,The Ideology of Bureaucracy in American Law“, 97 Harv. L. Rev. 1276, 1288-99 (1984.); Hegland, „Goodbye to Deconstruction“, 58 S. Cal. L. Rev. 1203 (1985.); Spann, „Deconstructing the Legislative Veto“, 68 Minn. L. Rev. 473 (1984.); Tushnet, „Critical Legal Studies and Constitutional Law: An Essay in Deconstruction“, 36 Stan. L. Rev. 623 (1984.); Note, „Overshooting the Target: A Feminist Deconstruction of Legal Education“, 34 Am. U. L. Rev. 1141 (1985.); Hutchinson, „From Cultural Construction to Historical Deconstruction“ (Book Review), 94 Yale L. J. 209, 229-35 (1984.).

12 J. M. Balkin, „Decontructive practice and legal theory“, 96 Yale L. J. 743 (1987.), p. 3. et passim. 
ljudske prirode u odnosu na neke druge. Poslije, kad opravdavamo svoj sistem, tvrdimo da je on najbolji, uzimajući u obzir prirodna ograničenja ljudskoga stanja. Npr. zagovornik laissez-faire može dokazivati da su npr. zadani samointeres ljudi, neregulirane tržišne transakcije itd. najbolji način ostvarivanja ljudskih ciljeva. Međutim, dekonstruktivna kritika podsjeća nas na to da naša socijalna vizija i pravni sistem nisu utemeljeni na ljudskoj prirodi kakva ona doista jest, već prije na interpretaciji ljudske prirode, metafori, privilegijima. Ne proživljavamo „,prisutnost“ ljudske prirode; proživljavamo njene različite verzije u pričama koje pričamo o tome kakvi smo doista. Takve su priče nepotpune, zato što su metafore one se mogu dekonstruirati. Često zaboravljamo da se naš pravni sustav temelji upravo na metafori i tumačenju; griješimo u pogledu dominantne ili privilegirane vizije naroda ili društva sa stvarno 'prezentnom' ljudskom prirodom, baš kao što je - primjećuje J. M. Balkin - J. J. Rousseau zamijenio govor s prisutnošću misli. Na tom mjestu metafora postaje pogrešna u odnosu na ono što opisuje. Ali u metafori je latentna protuvizija koja se može upravo putem dekonstrukcije locirati i iznijeti na površinu. Ona postoji unutar privilegirane koncepcije zato što protuvizija na ultimativan način ovisi u odnosu na razliku. ${ }^{13}$

\section{ADMINISTRATIVNA DRŽAVA: POSTANAK I UTJECAJ NA SISTEM OGRANIČENE VLADE ${ }^{14}$}

Nesporno je da je američka moderna država, koju karakterizira velika birokracija sa širokim upravljačkim ovlastima, nastala za vrijeme New Deala Franklina Roosevelta. Tada su novonastale agencije s birokracijom činile dio egzekutivne grane vlasti, ali su njene ovlasti uvelike transcendirale poznate tradicionalne granice. One su uključivale kako zakonodavne tako i sudske ovlasti, a obnašale su se na način koji je bio neovisan o predsjedničkoj i o političkoj kontroli. Iako povezana s New Dealom, intelektualni korijeni administrativne države povezuju se s idejama i utjecajem američkih progresista među kojima je Woodrow Wilson (1856. - 1924.) bio jedan od istaknutijih vođa.

Wilsonova je ideja bila da sve složenije društvo i njemu korespondirajuće ideje javne politike traže administrativne metode vlasti pogodne za učinkovito rješavanje problema. Išao je toliko daleko da je tvrdio kako su pitanja administracije od daleko praktičnijeg značaja za funkcioniranje američke vlasti nego li ustavna pitanja. Zato je primjena administrativnog upravljanja u više društvenih područja bila neizbježna i poželjna. „Ideja države i konzekventni ideal njene dužnosti prolazi kroz velike

13 J. M. Balkin, op. cit. p. 23. et passim; M. Tushnet, „Critical Legal Studies and Constitutional Law: An Essay in Deconstruction“, 36 Stan. L. Rev. 623 (1984.).

14 Šire o administrativnoj državi i odnosu prema konstitucionalizmu v. u Arsen Bačić i Petar Bačić, „Konstitucionalizam i administrativna država - O zahtjevima konstitucionalizma u razdoblju nadmoći egzekutive“, Zbornik radova Pravnog fakulteta u Splitu, god. 53, 1/2016., str. 119-137. 
promjene... kad pogledamo nove stvari koje država treba napraviti, sljedeća je stvar da vidimo jasno na koji način to moramo učiniti““. ${ }^{15}$

Kao profesor ustavnog prava i usporednih političkih sistema zagovarao je u svojim radovima tvrdnju da administrativna vlast bude, i mora biti, odvojena od političke vlasti. To upućuje na Wilsonovo razlikovanje između ustavnih i administrativnih pitanja u kojemu je problem administrativne diskrecije bio odvojen od pitanja koja su se određivala na temelju ustavnih principa. Oni su za Wilsona povezani samo onda kada politički dužnosnici izlažu administratorima zadaće i široke ciljeve te njihovo detaljno izvršavanje i implementiranje. Za Wilsona , administrativna pitanja nisu politička pitanja. Iako politika priprema zadaće za administraciju, ona ne smije trpjeti manipulaciju u svojim službama“. ${ }^{16}$

Wilson je povijest države u Europi i SAD-u dijelio na tri dijela. Prvi se temeljio na vladavini apsolutnih vladara, drugi na demokraciji i ustavima, a treći na administrativnoj državi koja se implementirala i dokazivala putem demokracije. U razdoblju ustavne države zanemarivala se učinkovita i uspješna administracija. No, krajem 19. stoljeća Sjedinjene Američke Države ulaze u treće razdoblje razvoja u kojemu polako nestaje ustavno nepovjerenje prema administraciji. Taj prijelaz iz ustavne u administrativnu državu bit će spor, ali nužan, a ispunjavat će ga demokratski instinkt biračkoga tijela.

\subsection{Founding fathers i progresisti - razlike u percepciji dobre vladavine}

Posljedice usvajanja ideja progresista kao temelja suvremenih američkih institucija vladanja bile su dugoročne, posebno kad se ima u vidu njihov utjecaj na originalne ideje američke ustavnosti. Najbolju ilustraciju predstavljaju sudske odluke povezane uz Chenery Case iz 1940. i 1947., ustvari niz događaja i neprilika povezanih uz restrukturiranje javne korporacije C. T. Chenery. ${ }^{17}$

Početkom 1935. godine, Kongres SAD-a donio je Public Utility Holding Act koji je tražio da javne kompanije reorganiziraju svoje korporativne strukture, a da kontrolu i potvrdu planova reorganizacije obavi novoformirana Securities and Exchange Commission (SEC). U zakonu nije bio označen nikakav poseban standard koji bi SEC koristio u evaluaciji takvih planova, niti su u zakonu postojali za SEC bilo kakvi pobliži propisi koji bi omogućavali njegovo djelovanje. Kada je na red za reorganizaciju došao Federal Water Service Corporation, njegova uprava C. T. Chenery Corporation nije imala pojma kako postupati u cilju ostvarivanja interesa kompanije. Kada je postalo jasno da bi SEC preferirao pretvaranje dioničarskih udjela iz stare kompanije u dionice novoorganiziranog poduzeća, Chenery Corporation je

15 Woodrow Wilson, ,The Study of Administration“, Political Science Quarterly, Volume 2, Number 2, June 1887., p. 201., https://ballotpedia.org/\%22The_Study_of_Administration\%22_by_Woodrow_ Wilson_(1887.).

16 W. Wilson, op. cit. 210.

17 Securities and Exchange Commission v. Chenery, 318 U.S. 80 (1943.), at 92-93; Securities and Exchange Commission v. Chenery, 332 U.S. 194 (1947.), at 202. 
za sebe kupio velik broj dionica na otvorenom tržištu. Iako je reorganizacijski plan što ga je SEC potvrdio dopuštao dioničarima konvertirati svoje dionice, SEC je izričito isključio Chenery iz takve pretvorbe lišavajući Chenery vlasništva. Razlog zbog kojega je SEC isključio Cheenery Corporation bio je u tome što je agencija odlučila kako je nedopustivo da upravljačka kompanija kupuje udjele za vrijeme reorganizacije. No u vrijeme kada je Chenery kupovao dionice takva zabrana ili pravilo zakonski nigdje nisu postojali, niti je zabrana pogodila bilo koga drugoga osim Chenery. Nije bilo ni zabrane da se SEC opet angažira u budućnosti. No, postojao je standard da je SEC oblikovan ad hoc i da se retroaktivno primjenjuje na jednu jedinu kompaniju. Kada je Chenery Corp. podnijela tužbu na federalni sud, protestirajući zbog očite povrede vladavine prava, SEC je računao na to da će sud prepustiti vještačenje agenciji i da će joj dopustiti svoje odluke izvršavati na bazi ,slučaj po slučaj“. Vrhovni sud 1943. god. zaključio je da SEC mora djelovati suglasno vladavini prava.

Ipak, četiri godine poslije, SEC je uspio postići naklonost Suda za svoje ad hoc odlučivanje. Održavajući spor živim, uvjerio je Sud da promijeni svoj stav tako da je 1947. Sud zaključio da bi svaki „rigidni“ zahtjev da agencije djeluju prema unaprijed stvorenim pravilima ,administrativni proces napravio nefleksibilnim i nesposobnim da riješi mnoge specijalizirane probleme koji bi se pojavili“. Za novi je Sud inzistiranje da agencije slijede preegzistentna pravila za donošenje svojih pravila predstavljalo „traženje kruha povrh pogače“. Drugim riječima, vladavina prava trebala je sjesti na stražnje sjedalo iza društvene svrsishodnosti koju je osiguravala ekspertna administracija.

Danas se Chenery case smatra prekretničkom odlukom iz područja administrativnog prava jer je pionirski primjer široke diskrecije dodijeljene birokratskim agencijama nakon što im je Kongres delegirao zakonodavne ovlasti. ${ }^{18}$

Očevi utemeljivači američke ustavnosti znali su da postoje dva načina organiziranja vlasti. Prvi sistem bio je sistem arbitrarne vladavine u kojemu vlast odlučuje kako djelovati na ad hoc osnovi; ovdje se odluka ostavljala na volji (kapricu) bilo kojemu službeniku ili službenicima koji su na dužnosti. Drugi je sistem implementacija sistema koji se temelji na vladavini prava, u kojemu se legalni propisi donose unaprijed i objavljuju pa oni obvezuju i vlasti i građane, dopuštajući potonjima da točno znaju što im je za činiti ili ne činiti kako bi izbjegli državnu prisilu. U slučaju Chenery, kompanija nije znala što i kako raditi da bi došla do svog vlasništva pa je bila prisiljena osloniti se na ad hoc odluke administratora

18 Vrhovni sud SAD-a je za vrijeme predsjednikovanja Willama Rehnquista (1924. - 2005.) jasno zauzeo stav da njegov sud neće revidirati niti odbaciti doktrinu non-delegation. U slučaju Mistretta $v$. United States, 488 U.S. 361 (1989.), Sud je podržao zakon koji je Saveznoj komisiji za kazne delegirao ovlasti odmjeravanja kazni (ili uputa za njihovo odmjeravanje) za najveći dio federalnih kaznenih djela. Ako je i postojao neki slučaj pogodan za reviziju doktrine, to je bio upravo taj slučaj. Kongres je stvorio U.S. Sentencing Commission suštinski kao privremenu legislaturu koja nije imala drugu svrhu nego da ozakoni i primjenjuje kazne za kažnjiva djela. Mistretta je ujedno i potvrda stava da federalni sudovi neće dovoditi u pitanje legitimnost administrativne države oživljavanjem podjele vlasti. Usp. Ronald Pestritto, The Birth of the Administrative State: Where It Came From and What It Means for Limited Government, 2007., p. 14. 
u SEC-u. Protiv takvog scenarija prednosti sistema vladavine prava i više su nego evidentne. ${ }^{19}$

Kako bi osigurali pojedinca u sistemu vladavine prava, Founding Fathersi su u ustavnu organizaciju vlasti ugradili mehanizam podjele vlasti. U ovom sistemu legitimnu vlast vrše tri jednake grane vlasti od kojih svaka mora biti sigurna da ostale vlasti ostaju unutar ustavom utvrđenog mjesta i granica. Temeljni cilj podjele vlasti bio je čuvanje prava pojedinca protiv arbitrarne vlasti. Za Jamesa Madisona (Federalist 47) tiranija je značila ništa drugo nego odsustvo diobe vlasti. No, dosljedna primjena ustavnog principa diobe vlasti značila je sljedeće: (i) nije bila moguća delegacija vlasti (nedelegiranje); jedna grana vlasti nije mogla u principu delegirati svoje ovlasti drugoj grani vlasti; (ii) nije bilo moguće da jedna grana vlasti kombinira više ovlasti; (iii) administracija je bila odgovorna egzekutivi. Ustav je svekoliku izvršnu vlast predao Predsjedniku SAD-a tražeći od njega da „brine o vjernom izvršavanju zakona“. Administracija je znači u potpunosti bila smještena unutar jedne grane vlasti. Postojala je jasna politička odgovornost administracije, a njeno je obnašanje vlasti bilo striktno ograničeno zakonom.

Upravo su navedena tri ograničenja kao dio legata ustavne podjele vlasti predstavljala posebnu prepreku viziji nacionalne administracije koju su na početku 20. stoljeća imali američki progresisti. Stara je podjela vlasti bila velika prepreka novom progresivnom liberalizmu, jer je originarni sistem institucija bio zamišljen za saveznu vladu koja je prema Ustavu i Deklaraciji o neovisnosti imala relativno ograničen broj ciljeva i instrumenata. Originalna projekcija zakonodavne vlasti Kongresa bila je pogotovo preskromna za njihova očekivanja u budućnosti. Zato su pristalice progresivnog liberalizma osmislili zakonodavnu delegaciju, odnosno delegaciju regulatornih ovlasti zakonodavaca u Kongresu na sve veći nacionalni administrativni aparat koji je zbog ekspertize i sposobnosti specijalizacije pokazivao više umješnosti i sposobnosti u upravljanju nizom pojedinosti koje obilježavaju modernu i složenu ekonomiju. Bilo je daleko efektivnije odgovornost prebaciti na posebnu agenciju koja bi zbog ekspertize bila u stanju kompetentnije donositi mjere i presuđivati sporove koji bi se pojavljivali u vezi s kršenjem njenih regulatornih mjera.

Ostvarivanje administrativne vizije progresivnog liberalizma tražilo je dakle odbacivanje doktrine nedelegiranja te usvajanje kombiniranja funkcija kao operativnog principa za rad administrativnih agencija. Kako je za progresiste ustavni položaj administracije unutar egzekutivne vlasti i pod kontrolom predsjednika bio problem, oni su nastojali izdvojiti administratore ne samo izvan dometa predsjednika SAD-a nego uopće izvan dometa politike. Dakle, temeljni cilj američkog progresivnoga pokreta bila je ideja odvajanja politike od administracije te utemeljenje njezina većeg dijela ne na suglasnosti naroda već na ekspertizi. Imajući to u vidu, onda je lako razumijeti žestoki napad progresivaca na konstitucionalizam podjele vlasti. A u toj intelektualnoj ofenzivi prednjačio je upravo Wudrow Wilson koji će poslije postati i 26. po redu izabrani predsjednik SAD-a i s tog položaja

19 Ronald Pestritto, op. cit. p. 2 et passim. 
snažno poticati jačanje administrativne države u SAD-u u prvoj polovici 20. stoljeća. ${ }^{20}$

\subsection{Administrativna država i ustavni dokumenti 20. i 21. stoljeća}

Komparativni pregled suvremenih ustava relativno nam malo otkriva i kazuje o administrativnoj državi iako je organizacija države i njena struktura središnja funkcija ustava. U organizacijskom dijelu ustava najčešće se nalaze detaljno regulirane odredbe o zakonodavnoj i izvršnoj funkciji, ali tek nekoliko i to površno reguliranih odredbi o ,subpolitičkim institucijama države“. Umjesto detaljnih odredbi za regulaciju administratora, pisani ustavi daleko se češće koncentriraju na garancije odgovornosti i demokratske legitimnosti svojih odluka. ${ }^{21}$

Ipak, ustavi itekako reflektiraju društvene promjene, kako globalne tako i one lokalne. Migracije ustavnih ideja snažno su obilježje suvremenoga svijeta. Između ostaloga, ustavi reflektiraju razvoj na planu tehnologije odnosno onoga što se danas uobičajeno naziva tehnologijom upravljanja (technology of governance). Ustavi danas, među ostalim, konstitucionaliziraju regulatorne agencije. Za razliku od Ustava SAD-a (1787.) koji, naravno, uopće ne spominje neovisne agencije, noviji ustavi ih spominju. Riječ je o institucijama administrativnoga prava poput ombudsmana, komisijama za ljudska prava, antikorupcijskim komisijama, revizijskim komisijama, komisijama za javne službe, za zapošljavanje, o upravnim sudovima... i niz drugih institucija kojima ustavi kontroliraju administrativnu državu. Unatoč lapidarnom karakteru ustavnih normi o legalnoj kontroli administracije, pisani ustavi i dalje predstavljaju temelje odgovornosti administrativne države. U tom smislu, posebno je važno pitanje istražiti pojavu administrativnog konstitucionalizma odnosno pitanje odgovornosti i legitimiteta u administrativnoj državi kao važnog područja relacije upravnog prava i demokratskog uređenja suvremene ustavne države.

\section{ADMINISTRATIVNI KONSTITUCIONALIZAM I PITANJE ODGOVORNOSTI I LEGITIMITETA U ADMINISTRATIVNOJ DRŽAVI}

U knjizi Williama Eskridgea i Johna Ferejohna A Republic of Statutes (2010.) autori istražuju fenomen administrativnog konstitucionalizma kao najznačajnije

20 Osim W. Wilsona, drugi veliki pristalica ideja progresivizma bio je profesor Frank Goodnow s Columbia University koji je u djelima Comparative Administrative Law (1893.), Politics and Administration (1900.), Social Reform and the Constitution (1911.) i The American Conception of Liberty and Government (1916.) kristalizirao agendu progresivaca posebno glede djelovanja sudova i uopće svrhe civilne vlasti.

21 Usp. Tom Ginsburg, Written Constitutions and the Administrative State: On the Constitutional Character of Administrative Law, University of Chicago Public Law \& Legal Theory Working Paper No. 331, 2010., p. 117-127. Tekst T. Ginsburga predstavlja poglavlje 7. knjige Comparative Administrative Law koji koristimo kao izvor podataka o ustavima i o administrativnoj državi. V. p. 123 et passim. 
karakteristike suvremene američke vladavine. Za ovu dvojicu istaknutih američkih konstitucionalista „Amerika danas uživa sustav zakona (constitution of statutes) koji dopunjuju i često zamjenjuju njezin pisani Ustav kao temeljne karakteristike vladavine". ${ }^{22}$ Riječ je o zakonima koji ne samo da popunjavaju ustavne praznine, već često i transformiraju Ustav kako ga se inače razumije. Središnja teza Eskridgea i Ferejohna jest tvrdnja da strukture upravljanja i norme koje su stvorene takvim odredbama protekom vremena postaju praksa i to zahvaljujući zakonodavnim i administrativnim djelovanjem. U tom smislu oni identificiraju administrativni konstitucionalizam kao proces u kojemu se odvija takav razvoj stvari. Prema ovom stajalištu administrativni konstitucionalizam uključuje ne samo tumačenje Ustava nego i...

,... agresivnu primjenu superstatuta od strane agencija kako bi one ostvarile svoju svrhu na operativan, koherentan način koji je konzistentan s drugim normativnim očekivanjima nacije“ (...),,administrativni konstitucionalizam jest proces u kojemu legislativni i egzekutivni službenici ... unapređuju nove temeljne principe i mjere". 23

Za razliku od sudbenog konstitucionalizma (judicial constitutionalism) koji autori sagledavaju kao proces koji je „,fundamentalno orijentiran prema definitivnim i principijelnim pravilima“, za njih je administrativni konstitucionalizam ,eksplicitno orijentiran prema eksperimentalnim i praktičnim politikama“. Iako naglašavaju djelovanje agencija i njihovih službenika, Eskridgeova i Ferejohnova je slika administrativnog konstitucionalizma kompleksna jer uključuje aktere izvan agencija u jednom dinamičnom, interaktivnom i promišljenom procesu ustavnog razvoja. To jednostavno znači da društveni pokreti i zakonodavna djelatnost zahtijevaju djelovanje agencija podložno javnoj kritici te ,,vetu od strane sudova, zakonodavnih tijela, ali i vetu drugih dužnosnika egzekutivne grane vlasti'”.

O važnosti administrativnog konstitucionalizma „kao eksplicitno orijentiranog procesa prema eksperimentalnim i praktičnim politikama“ možda najbolje govore sljedeći primjeri od kojih svaki podrazumijeva djelovanje federalnih agencija na interpretiranju i implementiranju ustavnog dokumenta. (i) Savezna uprava za hranu i ljekove (The U.S. Food and Drug Administration) usvojila je pravilo da tvornice duhanskih proizvoda na paketima proizvoda apliciraju slike upozorenja o rizicima zdravlja povezanih s pušenjem, odbacujući prigovore da tako vrijeđa I. i V. Amandman, (ii) Ministarstvo obrazovanja i Ministarstvo pravosuđa zajedno su stajali iza smjernica u kojima se objašnjavalo kako se osnovne i srednje škole mogu nositi s rasnim problemom koji bi bio konzistentan s ustavnim pravom. (iii) Ured tužitelja Ministarstva pravosuđa publiciralo je memorandum državnog tužitelja sa zaključkom da predsjednik SAD-a ima ustavnu mogućnost ovlastiti vojsku SAD-a da bude dio kampanje NATO-a u Libiji pa mu nije ni trebala potvrda Kongresa.

${ }^{22}$ William N. Eskridge Jr. \& John Ferejohn, A Republic of Statutes: The New American Constitution, Review by: Daniel Carpenter Perspectives on Politics, Vol. 10, No. 3 (September 2012), pp. $793-796$ (4 pages).

23 W. N. Eskridge Jr. \& J. Ferejohn, op. cit., p. 33. 
Unatoč njihova spornog sadržaja, ovi primjeri administrativnog konstitucionalizma počivaju na dobro poznatim zahtjevima ustavnog karaktera; o takvim zahtjevima agencije su se izričito suglasile imajući pritom u vidu i ustavnu jurisprudenciju Vrhovnoga suda.

Činjenica je da su se proteklih godina mnogi istraživači komparativnog ustavnog i upravnog prava šire fokusirali na međuigru između administrativnih aktera, nacionalne administrativne države i konstitucionalizma. Interes za administrativni konstitucionalizam gotovo je prirodni izdanak tekućih trendova u komparativnoj znanosti ustavnoga prava; o tome svjedoči interes (i) za tzv. „,popularni konstitucionalizam“, (ii) za povijesnu evoluciju ustavnog razumijevanja, (iii) kao i za ulogu ekstraustavnih mjera koje one imaju za konstrukciju temeljnih ustavnih zahtjeva. Imajući na umu dominaciju administrativne držve u SAD-u u razdoblju nakon New Deala, administrativno područje nužan je i važan element u naporima proširenja nacionalnog ustavnog horizonta. No, isto tako, administrativni je konstitucionalizam i logičan rezultat razvoja znanosti administrativnoga prava koje je danas naglašeno fokusirano na pitanja institucionalnoga dizajna i strukture internih agencija. Takav fokus vodi prema većoj pozornosti stvarnim događajima u agencijama i internoj dinamici kojom se one povezuju sa širim ustavnim pitanjima o obliku nacionalne vlade. Napokon, na rast administrativne države utječu politika i događaji iz neposrednog života. Nastanak nacionalne siguronosne države (security state), koji označava širenje predsjedničkih ovlasti uz ograničenje kongresnog ili sudbenog nadzora, osvijetlio je krucijalnu važnost konstitucionalizma izvršne grane vlasti. Svi različiti pristupi svode se zapravo na jednu jedinu značajnu poruku o potrebi uvažavanja ustavnoga karaktera upravnog i svakog drugog ordinarnog prava. $^{24}$

U evoluciji administrativne države i administrativnog prava vidimo ustrajne napore na usuglašavanju administrativne države s ustavnom strukturom. ${ }^{25}$ Taj je proces ukazao na problematiku političke odgovornosti, s rezultatom da su spomenuti napori previdjeli važnu prepreku legitimitetu agencija, a to je bila zabrinutost zbog arbitrarnosti administracije. Ovaj način razmišljanja evidentan je u prevladavajućem modelu administrativne države koji legitimitet agencija traži pozicioniranjem njihovih odluka pod čvrstu kontrolu predsjednika SAD-a kao izabranog dužnosnika koji odgovara čitavoj Naciji. Ipak, moglo bi se s dosta razloga tvrditi kako model „predsjedničke kontrole“ ne može legitimirati agencije i to iz razloga što on počiva na pogrešnoj pretpostavci kako je za njih dovoljna politička odgovornost, a ta je pretpostavka u dosluhu s premisom bliskom ustavnoj teoriji po kojoj je majoritarizam znak jednakosti za legitimnu vladu. Međutim, premisu o kojoj je posebno govorio Alexander Bickel danas propituje suvremena ustavna

24 Gillian E. Metzger, „Administrative Constitutionalism“, Texas Law Review, Vol. 91:1897, p. 1897-1935.

25 O modelima administrativne države tijekom 70-tih godina prošlog stoljeća v. Richard B. Stewart, „The Reformation of American Administrative Law“, 88 Harv. L. Rev. 1667 (1975.). 
teorija, ${ }^{26}$ a ona zastupa stajalište da majoritarizam više nije dovoljan za legitimaciju administrativnog odlučivanja u okvirima američke ustavne strukture baš zbog toga što ona nije pouzdana adresa koja bi vodila računa o odgovornosti.

Tako se L. S. Bressman zalaže za izravniji pristup sagledavanja arbitrarnosti kojemu je središnji interes briga za dobru vladavinu (good governance), a ne puka „odgovorna“" vlada u postbickelovskom majoritarnom smislu te riječi. Ona je uvjerena da izravniji pristup sugerira i nove mogućnosti za rješavanje dugo rješavanog problema legitimiteta agencija kao i nove načine razumijevanja trajnih zagonetki administrativnoga prava. ${ }^{27}$

Dakle, postavlja se sljedeće pitanje. Ako administrativni konstitucionalizam otvara perspektivu angažiranja agencija u rješavanju problematike koja implicira ustavna pitanja (značenje i doseg zakona), elaboraciju ustavnih značenja čak i onda kada ona interpretacijom i primjenom zakona koji počivaju na ustavnim vrednotama nesvjesno balansiraju ustavna pitanja, trebaju li onda sudovi i teorija prigrliti ili odbiti administrativni konstitucionalizam?

Za one koji vjeruju da su sudovi ekskluzivni i konačni interpreti ustava gotovo je prirodno protivljenje administrativnom konstitucionalizmu. Vrhovni sud SAD-a opirao mu se posljednjih 40 godina. Kada su agencije elaborirale ustavno značenje u svojim interpretacijama zakona, Sud im je odbijao prepustiti ono što je redovito tražila doktrina administrativnoga prava. Ipak, danas prevladava stav prema kojemu bi se administrativni konstitucionalizam trebao objeručke prigrliti. ${ }^{28}$ Razlozi za to su jednostavni. Da bi ustavni tekst koji ima svoju karakterističnu širinu i neodređenost ostao u životu, on se mora adaptirati promjenjivoj društvenoj okolini. Sudbeni konstitucionalizam adaptira značenja ustava novoj društvenoj stvarnosti, podešavajući ustavne principe derivirane iz njegova teksta. Ipak, ovaj je oblik konstitucionalizma ograničen u svojem kapacitetu osuvremenjivanja ustavnoga značenja. Prije svega zato što su suci podalje od promjenjive društvene stvarnosti, pa Narod nema mogućnost angažiranja u informiranoj raspravi o primjeni ustavnih principa u novom kontekstu ove ili one vrste. U tom smislu, administrativni konstitucionalizam postaje kritički dodatak sudbenom konstitucionalizmu u adaptiranju ustava promjenjivom društvenom kontekstu.

26 Alexander M. Bickel, The Least Dangerous Branch (2d ed. 1986). O fiksaciji ili opsesiji s majoritarizmom u ustavnoj teoriji v. Rebecca L. Brown, „Accountability, Liberty, and the Constitution“", 98 Colum. L. Rev. 531 (1998.); Barry Friedman, „The History of the Countermajoritarian Difficulty“, pt. 1: „,The Road to Judicial Supremacy“, 73 N.Y.U. L. Rev. 333 (1998.); Barry Friedman, ,The History of the Countermajoritarian Difficulty“, pt. 3: „The Lesson of Lochner“, 76 N.Y.U. L. Rev. 1383 (2001.); Barry Friedman, „The History of the Countermajoritarian Difficulty“, pt. 4: „Law's Politics“, $148 U$. Pa. L. Rev. 971 (2000.); Barry Friedman, „The Birth of an Academic Obsession: The History of the Countermajoritarian Difficulty“, pt. 5, 112 Yale L. J. 153 (2002.); Laura Kalman, „Law, Politics, and the New Deal(s)“, 108 Yale L. J. 2165 (1999.).

27 Lisa Schultz Bressman, Beyond Accountability: Arbitrariness and Legitimacy in the Administrative State, Social Science Research Network Electronic Paper Collection: http://ssrn.com/abstract_id=324540.

28 Bertrall L. Ross II., „Embracing Administrative Constitutionalism“, Boston University Law Review, Vol. 95:519, 2015., 519-585. 
Potonju koegzistenciju sudbene i agencijske primjene ustavnih principa B. L. Ross naziva ustavnim eksperimentiranjem, naime procesom koji promovira ustavnu adaptaciju dopuštajući iskušavanje operativnih učinaka raznih ustavnih aplikacija. Svjedočeći o rezultatima toga procesa, narod dolazi u situaciju da bude upoznat s faktima potrebnima za informiranu raspravu o tome koje aplikacije u promjenjivom društvenom kontekstu najbolje promiču relevantne ustavne principe. U takvom kontinuiranom procesu demokratske obnove prihvaća se pretpostavka da ustav može „trajati i za budućnost“ i „,adaptirati se različitim krizama ljudskih stanja“. ${ }^{29}$

Sve u svemu, moguće je iz prikazanog stanja sažeti dvije važne lekcije i to ne samo za aktualno stanje u SAD-u, nego i šire.

Prvo, očita je potraga teorije za nekim novim principima administrativnoga prava - npr. zahtjev da agencije koriste standarde koji vode, usmjeravaju i ograničavaju vlastitu diskreciju, kao i zahtjev da to čine općenito kroz prethodno upozoravajućei-komentirajuće usvajanje pravila i primjenu standarda na posebne situacije i činjenice. Usponom majoritarne paradigme u administrativnome pravu, ovi su se zahtjevi činili nelogičnima i lošima. Ali to je bilo zato što se nisu ni sagledavali kroz alternativnu paradigmu arbitrarnosti. Ako je riječ o troškovima koji idu uz te zahtjeve, npr. o izdacima koji prate fleksibilnost agencija, treba podsjetiti da su oni itekako „vrijedni svakog novčića“ ako to znači povratak agencijskog legitimiteta. Drugo, nova teorija naslanjat će se na „ordinarne“ principe upravnoga prava kao nikada ranije. Stanovito je vrijeme to naslanjanje na ,ordinarno" upravno pravo radi legitimacije administrativne vlasti izgledalo nezamislivim. Te su principe upravnog prava mnogi sagledavali samo kao autorizaciju sudske intervencije ili samopomoći agencija, a ništa od toga nije bilo opravdano ili korisno. Sad će, moguće, pokušati takvu percepciju majoritarnog mišljenja jednostavno ostaviti iza sebe.

Drugi su pak polazili od inferiornosti upravnoga prava prema ustavnom pravu, pa nisu ni otvarali pitanja o legitimnosti agencija. Danas je moguće kazati da je i takva percepcija bila kratkovidna jer je počivala na dihotomiji između kvantitete i kvalitete autoriteta administrativnoga odlučivanja. Naime, takva percepcija odvaja pitanje delegacije (odnosno na to koliko autoriteta Kongres može dodijeliti agencijama) kao pitanje „ustavnog“ upravnog prava, i pitanje izvršavanja (odnosno koliko agencije mogu vršiti te vlasti koju im dodijeli Kongres) što je pitanje „ordinarnog“ upravnog prava. No u svrhu legitimiranja administrativne države ta su pitanja međusobno isprepletena. Agencije legitimno posjeduju samo onoliko autoriteta koliko im daje Kongres da ga vrše u konzistenciji s principima pravednosti, racionalnosti i predvidivosti. A „ordinarno“ administrativno pravo nastoji osigurati da agencije djeluju konzistentno sa širokom javnom svrhom zakona koju oni implementiraju i drugim načinima kojima se promovira dobra vlada. ${ }^{30}$

29 Bertrall L. Ross II., op. cit., p. 585.

30 Charles R. Wise, „Public Administration Is Constitutional and Legitimate“, Public Administration Review, Vol. 53, No. 3 (May - Jun., 1993), pp. 257-261; Tim Hartford, „How a radical agency changed the world“, Financial Times - Weekend FT, 28 July/29 July, 2018., p. 9. 


\section{DEKONSTRUKCIJA ADMINISTRATIVNE DRŽAVE I PROMJENE UPRAVNOG PRAVA: MEĐUZAVISNOST I PODEŠAVANJE}

Javna administracija u svekolikim komparativnim oblicima služi političkim interesima par excellence jer ona mora implementirati akte i zakone zakonodavnoga tijela. Njena je veza s izvršnom granom vlasti strukturalna. To ponajbolje pokazuje upravo primjer SAD-a i njegov Ustav podijeljenih vlasti. U SAD-u Kongres i predsjednik mogu imati različite političke vizije i njihova je borba za usmjeravanje administrativne akcije imanentna. Kongres SAD-a u povijesnom je smislu igrao temeljnu ulogu u oblikovanju temeljnih pravila administrativnoga prava. The Administrative Procedure Act (1946.) bio je eksplicitna reakcija na ekcesivnu vlast predsjedničkog administrativnoga sustava koji je nakon Rooseveltova New Deala izgradio mrežu agencija sa širokim diskrecijskim prerogativima donošenja propisa i sudovanja. Postupno je Kongres u cilju kanaliziranja i kontrole budućih akcija birokracije preuzeo kontrolu nad administracijom i to uz pomoć različitih strukturalnih i proceduralnih instrumenata. ${ }^{31}$ Kongres je preko statutarne kontrole oblikovao strukturu i postupak djelovanja agencija kako bi favorizirao određene grupe i mjere u odnosu na neke druge. Putem kontrole izravno je nadgledao ponašanje agencija da bi došao do informacija treba li ispraviti ili kazniti nepoželjna ponašanja. Te su odluke autonomno donosili kongresni odbori i pododbori. Međutim, posljednjih trideset godina događa se svojevrsni revival predsjednikove administracije. Uvođenje analiza cost-benefit putem izvršnih naredbi predsjednika Ronalda Reagana (1981.) bila je prijelomna točka u tom smjeru. Kao rezultat političke odluke, bile su povučene iz agencija u Bijelu kuću kroz kontrolu koju su vodili Office of Information and Regulatory Affairs i Office of Management and Budget. U posljednjih nekoliko godina predsjednik je temeljem „,crnih“ i „sivih“ klauzula od Kongresa ishodio potvrdu određenih zakona. Black and grey zbog toga što egzekutivi daju široke ovlasti u implementaciji zakona. Temeljni argument kao što su situacije izvnrednosti (borba protiv terorizma, slom financijskih institucija) traže proširenje predsjedničkih ovlasti i razvitak fleksibilnog upravnog prava, s manje ograničenja ex ante i ex post. ${ }^{32} \mathrm{Na}$ isti je način takve tendencije jačao predsjednik Obama koji je na ključne administrativne pozicije postavljao lojalne

31 Mathew D. McCubbins \& Thomas Schwartz, „Congressional Oversight Overlooked: Police Patrols versus Fire Alarms“, 28 American Journal of Political Science 165, 167 (1984.); Mathew D. McCubbins, Roger Noll \&Barry R. Weingast, „Administrative Procedures as Instruments of Political Control“, 3 J. L. Econ. \& Org. 243 (1987.); John Ferejohn \& Charles Shipan, „Congressional Influence on Bureaucracy“, 6 J. L. Econ. \& Org. 1(1990.).

32 Eric A. Posner \& Adrian Vermeule, Crisis Governance in the Administrative State: $9 / 11$ and the Financial Meltdown of 2008, University of Chicago Law School, John Olin Law \& Economics Working Paper No. 440 (2008.); Adrian Vermeule, ,Our Schmittian Administrative Law“, 122 Harv. L. Rev. 1095 (2009.); Giulio Napolitano, ,, The Role of the State in (and after) the Financial Crisis: New Challenges for Administrative Law", u Comparative Administrative Law, p. 569. 
figure, pa je postalo evidentno kako predsjednički sustav potiče i hrabri „politizaciju birokracije". 33

U parlamentarnim sustavima politička veza između vlade i većine u parlamentu reducira konflikte pa egzekutiva izmiče kontroli zakonodavnog tijela čak i u slučajevima adminstrativne diskrecije. Ipak, u posljednje vrijeme parlamenti pokušavaju ponovno osvojiti svoju ulogu kao upravljači i kontrolori egzekutivnih radnji posebno u području delegiranog zakonodavstva, vođenja rata i zaključivanja međunarodnih ugovora. ${ }^{34}$

Međutim, iskustvo administrativne države u SAD-u, različitih korpusa javne administracije u Europi, kako na nacionalnoj, tako i na razini Europske unije, pokazuje nam...

... „da konflikti u administrativnom pravu nisu stvar jedne bitke. Svaki pokret jednog aktera ima odgovor u pokretima drugog. To je razlog zašto je administrativno pravo ponavljajuća interaktivna igra. Svaki pokret je nadogradnja i u vezi je s putem na kojemu se nalazimo. Sredstva i mehanizmi postavljeni u prijašnjoj rundi događaja ne mogu se tek tako i u potpunosti razmontirati. “35

\subsection{Bannonova dekonstrukcija države taking seriously?}

Vidjeli smo da je neposredno nakon ulaska u Bijelu kuću S. K. Bannon referirao s nizom pojmova koji su trebali obilježiti njegov mandat na poziciji glavnog stratega D. Trumpa. Ideje o ekonomskom liberalizmu, korporativnim medijima, dekonstrukciji države središnji su pojmovi ideologije populističke on-line zajednice Breitbart, vrlo definiranog kulturalnog i ideološkog pokreta koji je u posljednjih nekoliko godina arikulirao ,vrlo koherentnu priču o tome što je Amerika, što bi ona trebala postati, $i$ to ne samo s programom od nekoliko političkih mjera“. Naš je zadatak, govorio je Bannon, u najširem smislu...

... ,dekonstrukcija administrativne države... Ako pogledate sastav kabineta, vidjet ćete da su oni izabrani radi nekog razloga a taj je razlog dekonstrukcija. Način kako je progresivna ljevica vladala, bio je sljedeći, ako nešto nije prolazilo, trebalo je jednostavno stvar regulirati unutar odeđene agencije.

33 Bruce Ackerman, „Good-bye Montesquieu“, u Comparative Administrative Law, p. 127-131. Za P. L. Straussa politizacija se razmatra kao posljedica 'zakonodavne neodgovornosti Kongresa', P. L. Strauss, „Rule-making and the American Constitution“, u The Regulatory State. Constitutional Implications, 50, 63 (Dawn Oliver, Tony Prosser, \& Richard Rawlings eds., 2010.).

34 Giulio Napolitano, Conflicts and strategies in administrative law, $I \bullet C O N$ (2014.), Vol. 12 No. 2 , 357-369; doi:10.1093/icon/mou017.

35 Giulio Napolitano, op. cit., p. 368. 
Sve to treba dekonstruirati i upravo zato mislim da je pitanje regulacije toliko važno". 36

Američki su republikanci dugo angažirani u borbi protiv ekcesivne regulacije niza društveno političkih pitanja. S. K. Bannon je u svom nastupnom obraćanju američkoj javnosti zapravo ukazivao na problem koji po shvaćanju njegovih istomišljenika dolazi iz same dubine američke politike i prava: naime, na djelovanje administrativne države koju iz sjene inženjerski navode američki ,ljevičari“" radi ostvarivanja svojih političkih i ekonomskih ciljeva. U Bannonovoj percepciji takva država nije instrument američkog izbornog tijela, čak ni prepreka koju najčešće vide tvrdokorni konzervativci, već jednostavno urođeni neprijatelj američkog naroda. Administrativna država, to su sve strukture i funkcije države - za konzervativce „strano tijelo koje se uvlači virtualno u svaki aspekt američkog života“. ${ }^{37}$ Riječ je, dakle, o središnjem argumentu populističkih vođa koji se pojavljuju na tipičan način protiveći se institucijama i optužujući ih za sve društvene probleme da bi ih u praksi nakon konsolidacije vlasti jednostavno preuzeli za svoje ciljeve.

Ako je banonizam tek ,trumpizam s iskaznicom javne knjižnice“",38 je li Bannon sljedbenik Derride? Francuski pisac Alain Mabanckou (1966.) pita se: „Steve Bannon, mentor Trumpa, govori o 'dekonstrukciji' vlasti u Washingtonu. Dekonstrukciji? Čita li on Derridu?" Koliko on doista poznaje dekonstrukciju kao kritičku strategiju suvremene društvene misli? Neovisno o tom pitanju, mogli bismo reći da je Bannonova upotreba pojma korektna, iako u jednom drugom smislu. Naime, dekonstrukcija administrativne države jest terminus technicus koji se u sociologiji i političkim znanostima koristi uglavnom u analizi fiskalne države. Seebel Rahman u knjizi Democracy against Domination (2017.) raspravlja o dekonstruktivnoj snazi računalne fiskalne logike nad institucionalnim strukturama i regulatornom državnom birokracijom. U najvećem dijelu literature, kad god se spominje pojam dekonstrukcije administrativne države, on se izravno odnosi na rastavljanje fiskalnog regulatornog aparata. ${ }^{39}$ No očito je Bannonu kost u grlu welfare state i ono što ju je omogućavalo u prethodnom razvoju američkog društva i države, prije svega vladavina prava, s obzirom na to da je administrativna država još uvijek legalna struktura koja je na neki način bila supstitut legitimacije zbog deficita prezidencijalizma u egzekutivnoj grani vlasti. Adrian Vermuele ističe da je administrativna država najveći trijumf prava nakon slabljenja diobe vlasti. Bannon možda dobro zna da demokratsko društvo ne može poraziti sa stajališta suverene egzekutive jer se to mora učiniti ondje gdje vladavina prava i počiva,

36 The Interpreter, Stephen K. Bannon's CPAC Comments, Annotated and Explained, https://www. nytimes.com/2017/02/24/us/politics/stephen-bannon-cpac-speech.html.

37 Francis Wilkinson, Bannon's Requiem for the Administrative State, https://www.bloomberg.com /view/articles/2017-03-27/bannon-s-requiem-for-the-administrative-state.

38 „Bannonism, which seems like little more than Trumpism with a library card, requires its share of administrative detail“. Usp. F. Wilkinson, op. 2.

39 K. Sebeel Rahman. Democracy against Domination. Manhattan: Oxford University Press, 2016. 
a upravo tu administrativna država igra fundamentalnu ulogu. ${ }^{40}$ Upravo zato Bannon govori o dekonstrukciji administrativne države; njegova dekonstruktivna gesta stremi ići u samo srce vladavine prava koju su „dobri Amerikanci“ nakon izbora već gledali kao nezamjenjivi „kontrolni mehanizam Trumpovog bijesnog egzekutivnog unilateralizma“". ${ }^{41}$ Zato G. Munoz s pravom zaključuje da Derrideova dekonstrukcija ima vrlo malo veze s Bannonovim napadom na institucije države blagostanja. Bannon se, dakle, samo ovlaš naslonio na transparentni konceptualni rezervoar lingvističkih fraza suvremene misli, ali ta njegova hiperbola izgubila je svu prednost u njegovu pokušaju da uništi i opstruira ono što je nadživjelo sve predsjednike SAD-a. Naime, ekspanzivnu regulatornu agendu kojoj izgleda nema kraja u svijetu koji nas okružuje. ${ }^{42}$

\section{ZAKLJUČAK}

Kontroverze oko administrativne države u SAD-u predstavljaju danas najuočljiviju sliku javnoga prava kao mjesto konflikta u kojemu se politički, institucionalni i ekonomski akteri natječu i pregovaraju. Ipak, takav dojam ne treba prenaglašavati jer postoje i neke druge njegove vizije čija nam objašnjenja počesto nude jasnije viđenje prave suštine i prave dinamike suvremnog pravnoga poretka. $U$ tom smislu, u svojoj analizi konflikata i strategija u suvremenom upravnom pravu, G. Napolitano ističe potrebu uvažavanja dviju važnih napomena:

„Prvo, (...) upravno pravo ... je u suvremenoj ustavno-demokratskoj državi instrument ekonomskog, socijalnog i kulturalnog napretka (...) njegova pravila donijeta s jednom svrhom mogu ispuniti suprotna očekivanja, čak i onda kad se takav rezultat ne očekuje. A razvoj takvih aktiviranih pravila teško je predvidjeti unaprijed.

Drugo, politički, institucionalni i ekonomski akteri nisu jedini relevantni igrači u upravnom pravu. Na razvitak ovoga prava duboko utječu birokrati i suci. Oni nisu samo neutralni, mehanički i pasivni akteri ... Štoviše, oni često raspolažu sa superiornom ekspertizom, kojom oni utječu ili dezinformiraju političke, institucionalne i ekonomske aktere. Upravo iz toga razloga u konfliktima unutar upravnog prava birokrati su jednom vjerni vojnici a u drugoj prilici autonomna vojska, baš kao što su i suci u jednom slučaju mirotvorci a u drugom palikuće.“"43

40 Adrian Vermeul, Law's Abnegation: From Law's Empire to the Administrative State, 1st Edition, 2016., pp. 23-26; Adrian Vermeule, The Administrative State: Law, Democracy, and Knowledge, Harvard Public Law Working Paper No. 13-28, 26 Pages Posted: 24 Sep 2013 Last revised: 1 Nov 2013.

41 Usp. F. Wilkinson, op. cit. 4.

42 Gerardo Muñoz, An explanation for 'deconstructing the administrative state', March 7, 2017. https://infrapolitica. com/2017/03/07/an-explanation-for-deconstructing-the-administrative-state-bygerardo-munoz/

43 G. Napolitano, Conflicts and strategies in administrative law, $I \bullet C O N$ (2014.), Vol. 12 No. 2 , 357 369, doi:10.1093/icon/ mou017. 
Mnogi su američki predsjednici pokušavali demontirati administrativnu državu koja je za sve njih bila i ostala oličenje Behemota. Ronald Reagan tvrdio je kako država nije rješenje životnih problema jer je ona sama problem. Njegov pokušaj da razruši welfare state i oslabi birokraciju nisu završili trijumfom. Ono što je vrijedilo za predsjednike od Roosevelta preko Obame pa do Trumpa danas je zapravo njihovo nastojanje da uspiju usmjeriti birokraciju gdje cee djelovati i koliko će na to potrošiti vremena kako bi ostvarili ciljeve koje predsjednici žele ostvariti. A kako se nama čini, riječ je o iskustvu koje mnogima izvan te najrazvijenije ustavne demokracije svijeta nije ni nepoznato ni daleko.

\section{DECONSTRUCTION OF AN ADMINISTRATIVE STATE AND POSSIBILITY OF PUBLIC LAW}

This paper opens up the concept of „deconstruction "of administrative states in the USA as its representative example. Starting from the domination of a modern administrative state, the full picture of modern constitutionalism in the USA must include administrative constitutionalism as overall understanding and interpretation of a modern administrative state and its structure by agencies and other active participants in administrative law. Administrative constitutionalism is today one of the most intensively studied subjects of investigation of comparative constitutional and administrative law. The reason for exegesis of this issue is not only its various dimensions but also the fact that it represents the main mechanism which today elaborates and implements constitutional meaning.

Key words: administrative state, deconstruction of administrative state, administrative constitutionalism, constitutional law, administrative law 